\title{
Return of Corruption Assets toward Criminal Actions of Office
}

\section{Abuse}

\author{
Rahmayanti \\ Panca Budi Development University, Indonesia \\ rahmayanti@dosen.pancabudi.ac.id
}

\begin{abstract}
Corruption is a serious problem because it can endanger the stability and security of society, destroy democratic values and morality, and endanger economic, socio-political development, and create massive poverty so that it needs attention from the government and society and social institutions. The purpose of this study is to determine and analyze the sanctions arrangements for corruption in the abuse of office and the return of assets resulting from corruption against criminal acts of abuse of office based on Law Number 31 of 1999 in conjunction with Law Number 20 of 2001 concerning Corruption Eradication. The research that was conducted was juridical normative, the data source used to support this research was secondary data sources. The return of assets from corruption has occupied an important position in eradicating corruption. a criminal act of corruption is an act directly related to the authority (bevoegheid), the right to rule or act as the power of a public official to comply with the rule of law in the scope of carrying out public obligations. The return of assets is based on the principles of social justice which gives the ability, duty and responsibility to state institutions and legal institutions to provide protection and opportunities for individuals in society to achieve prosperity, so that this is in line with the objectives of the State as specified in UUD 1945.
\end{abstract}

Keywords

assets, corruption

crime; abuse of position

\section{Introduction}

In the Indonesian Encyclopedia, it is called "Korupsi" (from Latin: corruption = bribe; corruptore $=$ destructive) a symptom in which officials, state agencies abuse their authority by the occurrence of bribery, falsification and other irregularities. ${ }^{1}$ Corruption is a bad act such as embezzlement of money, receiving bribes and so on. ${ }^{2}$ Corruption is a serious problem because it can endanger the stability and security of society, destroy democratic values and morality, and endanger economic, socio-political development, and create massive poverty so that it needs attention from the government and society and social institutions. One of the efforts to reduce the high rate of corruption is prevention. The KPK's serious effort in eradicating corruption with a preventive approach is a smart effort. This approach shows that the KPK realizes that a better future for the nation needs to be prepared with people who understand the dangers of corruption for the nation's civilization.

Basically, the prevention of crimes or criminal acts of increasing intensity in people's daily lives is aimed at creating domestic security. Domestic security is the main requirement to support the creation of a just, prosperous and civilized civil society based

\footnotetext{
${ }^{1}$ Evi Hartanti,Tindak Pidana Korupsi-Edisi Kedua,Sinar Grafika, Jakarta, 2012, P. 8

2 Emansyah Djaja, Memberantas Korupsi Bersama Komisi Pemberantasan Korupsi-KPK, Sinar Grafika, Jakarta, 2009, P. 7.
} 
on Pancasila and the 1945 Constitution of the Republic of Indonesia (abbreviated to the 1945 Constitution of the Republic of Indonesia). ${ }^{3}$

The criminal act of corruption is an extraordinary crime because it hinders the goal of the state for the welfare of its citizens. ${ }^{4}$ Corruption is a specific criminal act which is regulated outside of the Criminal Code, Corruption is a criminal act which involves bribery manipulation and acts against the law that are detrimental or can harm the country's finances or the country's economy, detrimental to the welfare or interests of the people / general (Zulyadi, 2020). Corruption practices such as abuse of authority, bribery, giving facilitation payments, illegal fees, giving rewards on the basis of collusion and nepotism and the use of state money for personal interests, are interpreted as acts of corruption and are considered common in this country (Sidi (2019) in Kartika, 2020).

Officials are not only limited in authority and power but need each other and there must be cooperation. Sometimes the regularity in exercising authority and power regulated by law is disturbed if there is an official who exceeds the limits of their authority or power. In such cases, there will be a violation or abuse of power. ${ }^{5}$ Tolerance and indifference facilitate violations and abuse of authority and power ${ }^{6}$.

Misusing the authority, means or opportunities available to him because of the position or position is a term used by legislators to describe the unlawful nature of the criminal act of corruption (Article 3, Law No. 31 of 1999). So, if an act is against the law according to Article 2 paragraph (1) of Law No. 31 of 1999, considering that the article uses the term against the law to describe its unlawful nature, then mutatis mutandis, that act also cannot be viewed as an act against the law according to any article, including not an act of abusing authority as referred to in Article 3, Law Law No. 31 of 1999. ${ }^{7}$

Corruption assets are a state right that must be returned to the state and it is the state that has the right to manage state assets or assets and be used as much as possible for the prosperity and welfare of the people. The return of assets resulting from criminal acts of corruption is a relatively new legal issue and as a development of public demands, both nationally and internationally. State financial losses due to criminal acts of corruption have not been covered and public unrest is still high on law enforcement for criminal acts of corruption in Indonesia.

Considering that the problem of corruption is related to state money, it is also an obligation of the state to take it back which is the right of the state by holding the perpetrators accountable, in this case of accountability the public only knows by imprisoning the perpetrators of corruption themselves, so it seems that this corruption problem is dominating Criminal law alone, but don't forget it turns out that holding corruptors accountable to return state assets can also be done through Civil Law with

\footnotetext{
${ }^{3}$ According to Sri Endah Wahyuningsih, that in realizing the noble ideals of the Indonesian nation, apart from a policy approach, if the crime is to be used as a means to achieve these goals, the humanistic approach must be considered. This is important not only because the crime is essentially a humanitarian problem, but also because in essence the crime itself contains elements of suffering that can attack the most valuable interests or values for human life.. (Sri Endah Wahyuningsih, 2010, Prinsip-prinsip Individualisasi Pidana Dalam Hukum Pidana Islam, Cetakan Pertama Juli 2010, Badan Penerbit Universitas Diponegoro, Semarang, P. 17.)

${ }^{4}$ The conception of a welfare state is adopted in the 1945 Constitution of the Republic of Indonesia (UUD 1945), to be precise in the 4th paragraph of the Preamble to the 1945 Constitution, by placing the phrase 'advancing the general welfare' as one of the ideals of the Republic of Indonesia.. Fadli Prasetyo dan Kukuh, 2012, Politik Hukum di Bidang Ekonomi dan Pelembagaan Konsepsi Welfare State di dalam UndangUndang Dasar 1945, Jurnal Konstitusi Vol. 9 No. 3, P. 495-514.

${ }_{5}^{5}$ Mochtar Kusumaatmadja dan B. Arief Sidharta,Pengantar Ilmu Hukum,Alumni, Bandung,2000, P. 41

${ }^{6}$ Ibid

${ }^{7}$ Undang-Undang No. 31 Tahun 1999 tentang Pemberantasan Tindak Pidana Korupsi
} 
claims for compensation and State Administrative Law / politics by giving administrative sanctions. Based on the written background, the main problems in this research are: (1) How are the sanctions arrangements for criminal acts of corruption in the abuse of office? (2) How is the return of assets resulting from corruption against criminal acts of abuse of office?

\section{Research Methods}

This research is descriptive analytical in which the researcher will describe the problem of legal rules related to the regulation of sanctions against criminal acts of corruption in the abuse of office and the return of assets resulting from corruption based on Law Number 31 of 1999 in conjunction with Law Number 20 of 2001 concerning Corruption Eradication. The approach used is an empirical juridical approach, which is an approach that looks from a juridical perspective (applicable regulations or norms) supported by an empirical juridical approach (law enforcement practices that occur in the field).

\section{Results and Discussion}

\subsection{Regulation of Sanctions Against Corruption in Misuse of Position}

The imposition of sanctions against criminal acts of corruption in Indonesia, will be given to every person who violates the law or violates the rules, both criminal, social and administrative sanctions in general, the sanctions given to perpetrators of corruption as regulated in Law Number 20 of 2001 concerning Amendments to Law Number 31 of 1999 concerning Eradication of Corruption Crimes include death penalty, imprisonment, and additional punishment.

The criminal system for criminal acts of corruption stipulates a special minimum threat and a special maximum. In the criminal act of corruption, the maximum imprisonment punishable far exceeds the maximum in the Criminal Code of 15 years. In the Criminal Code, the criminal act of corruption cannot be imposed with a death penalty as a principal punishment which is punishable by an independent crime. The application of sanctions against the perpetrators of corruption, namely Dadang Iskandar and Abdul Manaf, in connection with the alleged corruption case. The legal facts show that Dadang and Abdul Manaf were legally and convincingly proven guilty according to the law of committing a criminal act of corruption. The judge's decision against Dadang Iskandar was imprisoned for 2 (two) years and 4 (four) months and a fine of Rp. 50,000,000 (fifty million rupiah) as well as the judge's decision against Abdul Manaf for 1 (one) year and a fine of $\mathrm{Rp} .50,000.000$ (fifty million rupiah) which if the fine is not paid is replaced by imprisonment for 2 (two) months is deemed In addition to the imposition of imprisonment and additional penalties as referred to in Article 18 paragraph (1) letter b, paragraph (3), Law Number 20 Year 2001 Concerning Amendments to Law Number 31 Year 1999 Concerning the Eradication of Corruption Crime, the application of criminal sanctions is deemed less effective in ensnaring and providing a deterrent effect for perpetrators of criminal acts of corruption, incompatible with the government's efforts to restore state finances as well as the impoverishment of the corruptors as an effort to eradicate the criminal act of corruption.

Tatiek Sri Djatmiati, in the context of corruption, abuse of power (abuse of authority) or unreasonableness (arbitrary), both of which are the main parameters of whether or not there are deviations in the use of governmental authority, of course in addition to other 
principles of administrative law. In the event that there is an element of abuse of authority and arbitrarily, then there is an element of maladministration and of course there is an element of acts against the law, and the act becomes the personal responsibility of the official who commits it. Abuse of power has a broader understanding than unreasonableness, but in the study of administrative law both are very necessary to determine the presence or absence of occupational corruption. ${ }^{8}$

Article 19 of Law Number 30 Year 2014 further regulates the legal consequences of a decision and / or action that meets the criteria for abuse of power, as follows: ${ }^{9}$

1) Decisions and / or Actions which are determined and / or carried out beyond the Authority as referred to in Article 17 paragraph (2) letter a and Article 18 paragraph (1) as well as Decisions and / or Actions which are determined and / or carried out arbitrarily as referred to in Article 17 paragraph (2) letter c and Article 18 paragraph (3) are invalid if they have been tested and there is a Court Decision that has permanent legal force.

2) Decisions and / or Actions stipulated and / or carried out by confusing the Authority as referred to in Article 17 paragraph (2) letter b and Article 18 paragraph (2) can be canceled if they have been tested and there is a Court Decision with permanent legal force.

The application of sanctions against criminal acts of corruption in Indonesia, will be given to every person who violates the law or violates the rules, whether criminal, social, or administrative sanctions in general, the sanctions given to perpetrators of criminal acts of corruption are regulated in Law Number 20 of 2001. Regarding Amendments to Law Number 31 of 1999 concerning Eradication of Corruption Crime. The system of punishment in general is different from punishment in special crimes. Regarding the main criminal law, although the types of crimes in the criminal law of corruption are the same as the general criminal law, the system for the imposition of the penalties has a specificity when compared to the general criminal law, as follows: Imposing two types of main crimes which are imperative in nature and the imposition of two types of main crimes simultaneously which are imperative and facultative. The application of sanctions against the perpetrators of criminal acts of corruption besides the application of imprisonment, additional penalties, namely the application of fines, are deemed less effective in ensnaring and providing a deterrent effect for the perpetrators of corruption.

\subsection{Return of Corruption Proceeds Asset against the Crime of Misuse of Position}

Corruption is a form of illegal action that is very dangerous to the state of state finances, imagine that state finances that have been stipulated in the APBN or APBD must be reduced because they are taken by irresponsible people and of course it will result in obstruction of state development because the results of corruption are difficult to be returned, moreover, a lot of funds disbursed are not in accordance with the development itself, so that the expected objectives are not achieved. Therefore, perpetrators of corruption must be held accountable so that state assets can be returned in various ways, namely through civil, criminal and state / political administration channels. ${ }^{10}$ The return of

\footnotetext{
${ }^{8}$ Philipus M. Hadjon dkk, Yogyakarta, Gadjah Mada Uniersity Press, 2011, hlm 16-17

9 Rini, Nicken Sarwo. 2018. Penyalahgunaan Kewenangan Administrasi dalam Undang-Undang Tindak Pidana Korupsi. Jurnal Penelitian Hukum DE JURE, ISSN 141-5632 vol.18 No. 2, Juni 2018, 265.

${ }^{10}$ Purwaning M. Yanuar, Pengembalian Aset Hasil Korupsi, (Bandung: Alumni, 2007), halaman 201
} 
assets from corruption has occupied an important position in eradicating corruption. ${ }^{11}$ Purwaning M. Yanuar, formulating the definition of return of assets resulting from criminal acts of corruption, namely ${ }^{12}$

"The law enforcement system carried out by the victims of corruption is to revoke, seize and eliminate the rights to assets resulting from corruption crimes from the perpetrators of corruption through a series of processes and mechanisms, both criminal and civil, of assets resulting from criminal acts of corruption, either who are inside or outside the country, are tracked, frozen, confiscated, confiscated, handed over and returned to the victim country as a result of the crime of corruption, so that they can recover state financial losses caused by criminal acts of corruption and prevent perpetrators of criminal acts of corruption from using assets. proceeds of the criminal act of corruption as a tool or means of committing the proceeds of other crimes and providing a deterrent effect on the perpetrators and / or potential perpetrators of the criminal act of corruption.

In the criminal act of corruption, an act is directly related to authority (bevoegheid), namely the power of law, the right to rule or act as the power of a public official to comply with the rule of law in the scope of carrying out public obligations. Meanwhile, the Theory of Returning Assets from Corruption is a theory that explains a legal system of returning assets based on the principles of social justice that provides the ability, duties and responsibilities to state institutions and legal institutions to provide protection and opportunities to individuals in society to use them. to achieve prosperity, so that this is in line with the objectives of the State as stipulated in the 1945 Constitution.

The legal concept of recovering assets according to Indonesian criminal law is: an additional punishment that can be imposed by the judge, together with the principal punishment. Article 39 paragraph (1) of the Criminal Code states that "Items belonging to the convicted person obtained from a crime or which are deliberately used to commit a crime, can be confiscated". Article 39 of the Criminal Code further regulates which goods (assets) can be confiscated. Sanctions that are heavy in principle, will only be imposed if other, lighter law enforcement mechanisms have become ineffective or have been deemed unsuitable. Criminal law sanctions must be commensurate and proportional to what the perpetrator of the crime actually does. The form of sanction "impoverishment" includes restorative justice efforts where the perpetrator of a criminal act must return to his original condition before he commits a crime of corruption. The enforcement of justice in question is not only imposing sanctions that are appropriate for the perpetrators but also paying attention from the side of justice for victims who have been harmed, namely returning stolen state assets, ${ }^{13}$ even the profits derived from the proceeds of the crime.

The definition of the assets of a criminal act as mentioned above is not clear if it is related to the sound of Article 4 of the draft law, which reads: Assets of a criminal act that can be confiscated, include: Assets obtained directly or indirectly from a criminal act, including assets which are later incorporated into it. converted, changed or combined with the wealth that was generated or obtained directly from the crime, including income, capital or other economic benefits obtained from such assets; ${ }^{14}$

\footnotetext{
${ }^{11}$ Badan Pembinaan Hukum Nasional Departemen Hukum dan Hak Asasi Manusia RI, Laporan Lokakarya Tentang Pengambilan Aset Negara Hasil Tindak Pidana Korupsi (Jakarta: Badan Pembinaan Hukum Nasional, 2009). hlm. 53.

${ }^{12}$ Purwaning M. Yanuar, Pengambalian Aset Hasil Korupsi: Berdasarkan Konvensi PBB Anti Korupsi 2003 Dalam Sistem Hukum Indonesia (Bandung: Alumni, 2007)., hlm. 104.

${ }^{13}$ Jan Remmelink, Hukum Pidana (Jakarta: Gramedia Pustaka Utama, 2003). hlm 15.

${ }^{14}$ Ibid
} 
a) Assets that are reasonably suspected to be used or have been used as facilities or infrastructure to commit a criminal act;

b) Assets related to a criminal act in which the suspect / defendant has died, escaped, has been permanently ill, whose whereabouts are unknown or for other reasons;

c) Assets in the form of found items; and or

d) Other assets that are valid as a substitute for assets of a criminal act.

Then state losses legally can be linked to discretion from government officials, because of the presence or presence of the word "can" in the phrase "which can harm the State finances or the country's economy" as mentioned in Article 2 paragraph (1) and Article 3 of Law no. 31 of 1999 Jo. UU no. 20 of 2001 Corruption Eradication.

The act of returning the assets proceeds of corruption as an effort to minimize state losses caused by corruption is an effort that is no less important than punishing the perpetrator with the heaviest penalty. The return of assets resulting from criminal acts of corruption is to minimize the state's losses, besides it must be carried out from the beginning of the case handling process, it is also absolutely necessary to collaborate with various state institutions which must also be facilitated with the assistance of financial intelligence. ${ }^{15}$ The first stage of returning the assets of a criminal act of corruption is the asset tracking stage. To keep the scope and direction of investigations in focus, according to John Conyngham, the authorities conducting the investigation or tracking the assets partner with law firms and accounting firms. ${ }^{16}$ For the purpose of investigation, the presumption is formulated that the perpetrator of a criminal act will collateralize the funds obtained illegally for personal and family interests.

\section{Conclusion}

1. The imposition of sanctions against criminal acts of corruption in Indonesia, will be given to every person who violates the law or violates the rules, whether criminal, social, or administrative sanctions in general, the sanctions given to perpetrators of corruption are regulated in Law Number 20 Of 2001 concerning Amendments to Law Number 31 of 1999 concerning Eradication of Corruption Crimes. Article 19 of Law Number 30 of 2014 further regulates the legal consequences of a decision and / or action that meets the criteria for abuse of power.

2. The return of assets of a criminal act of corruption can be confiscated, namely by means of assets obtained directly or indirectly from a criminal act, including assets which are then converted, changed or combined with assets generated or obtained directly from the crime, including income, capital or other economic benefits derived from wealth. The act of returning the assets resulting from the crime of corruption as an effort to minimize state losses caused by the criminal act of corruption is an effort that is no less important than punishing the perpetrator with the heaviest penalty.

\footnotetext{
${ }^{15}$ Suradji, Buguati, Sutriya, ed., Pengkajian Tentang Kriminalisasi,Pengembalian Aset, Kerjasama Internasional dalam Konvensi PBB, Badan Pembinaan Hukum Nasional Departemen Hukum dan HAM, Jakarta, 2008, hlm 9.

${ }^{16}$ John Conyngham, ESq., Global Dirrector of Investigations, Control Risks Group Limited Before the Institutions and Consumer Credit US House Representatives, 9 May 2002, hlm 2
} 


\section{References}

Badan Pembinaan Hukum Nasional Departemen Hukum dan Hak Asasi Manusia RI, 2009, Laporan Lokakarya Tentang Pengambilan Aset Negara Hasil Tindak Pidana Korupsi (Jakarta: Badan Pembinaan Hukum Nasional).

Emansyah Djaja, 2009, Memberantas Korupsi Bersama Komisi Pemberantasan KorupsiKPK,Sinar, Jakarta Grafika.

Evi Hartanti, 2012, Tindak Pidana Korupsi, Jakarta, Sinar Grafika.

Jan Remmelink, 2003, Hukum Pidana, Jakarta: Gramedia Pustaka Utama.

John Conyngham, ESq., Global Dirrector of Investigations, Control Risks Group Limited Before the Institutions and Consumer Credit US House Representatives, 9 May 2002, hlm 2.

Kartika, A. (2020). The Urgency of the Criminal Provision Regulationss in Cooperatives Law at Indonesia. Budapest International Research and Critics Institute-Journal (BIRCI- Journal). P. 947-955.

Kitab Undang-undang Hukum Pidana

Konsepsi negara kesejahteraan diadopsi di dalam Undang-Undang Dasar Negara Republik Indonesia Tahun 1945 (UUD 1945), tepatnya di dalam alinea ke-4 Pembukaan UUD 1945, dengan menempatkan frase 'memajukan kesejahteraan umum' sebagai salah satu cita negara Republik Indonesia. Fadli Prasetyo dan Kukuh, 2012, Politik Hukum di Bidang Ekonomi dan Pelembagaan Konsepsi Welfare State di dalam UndangUndang Dasar 1945, Jurnal Konstitusi Vol. 9 No. 3, hlm. 495-514.

Mochtar Kusumaatmadja dan B. Arief Sidharta, 2000, Pengantar Ilmu Hukum, Alumni, Bandung.

Philipus M. Hadjon dkk, 2011, Yogyakarta, Gadjah Mada Uniersity Press.

Purwaning M. Yanuar, 2007, Pengembalian Aset Hasil Korupsi, Bandung: Alumni

Purwaning M. Yanuar, 2007,Pengambalian Aset Hasil Korupsi: Berdasarkan Konvensi PBB Anti Korupsi 2003 Dalam Sistem Hukum Indonesia, Bandung: Alumni.

Rini, Nicken Sarwo. 2018. Penyalahgunaan Kewenangan Administrasi dalam UndangUndang Tindak Pidana Korupsi. Jurnal Penelitian Hukum DE JURE, ISSN 141-5632 vol.18 No. 2, Juni 2018, 265.

Sidi, R. (2019). Corruption Prevention Efforts with Non Penal Policy. Britain International of Humanties and Social Sciences(BIoHS)Journal. P. 53-63

Sri Endah Wahyuningsih, 2010, Prinsip-prinsip Individualisasi Pidana Dalam Hukum Pidana Islam, Semarang, Badan Penerbit Universitas Diponegoro.

Suradji, Buguati, Sutriya, ed., 2008, Pengkajian Tentang Kriminalisasi,Pengembalian Aset, Kerjasama Internasional dalam Konvensi PBB, Jakarta, Badan Pembinaan Hukum Nasional Departemen Hukum dan HAM.

Undang-undang Dasar 1945

Undang-undang Nomor 11 Tahun 1980 tentang Pidana Suap

Undang-undang Nomor 3 Tahun 1971 Tentang Pemberantasan Tindak Pidana Korupsi.

Undang-undang Nomor 31 Tahun 1999 jo Undang-undang Nomor 20 Tahun 2001 Tentang Pemberantasan Tindak Pidana Korupsi.

Undang-undang Nomor 30 Tahun 2002 Tentang Komisi Pemberantasan Korupsi

Undang-undang Nomor 8 Tahun 1981 tentang Kitab Undang-undang Hukum Acara Pidana

Zulyadi, R. (2020). Judge's Role in Court to Eradicate Corruption According to Law Number 20 in 2001 (Study of Decision 16/PID.SUS.K/2011/PN.MDN). Budapest International Research and Critics Institute-Journal (BIRCI-Journal). P. 1280-1288. 